\title{
Staphylococcus nepalensis sp. nov., isolated from goats of the Himalayan region
}

\author{
Correspondence \\ Hans-Jürgen Busse \\ hans-juergen.busse@ \\ vu-wien.ac.at
}

\author{
Joachim Spergser, ${ }^{1}$ Monika Wieser, ${ }^{1}$ Martin Täubel, ${ }^{1}$ Ramon A. Rosselló- \\ Mora, ${ }^{2}$ Renate Rosengarten ${ }^{1}$ and Hans-Jürgen Busse ${ }^{1,3}$ \\ ${ }^{1}$ Institute of Bacteriology, Mycology and Hygiene, University of Veterinary Medicine, \\ Veterinärplatz 1, A-1210 Vienna, Austria \\ ${ }^{2}$ Cientific Titular CSIC, GOI, IMEDEA (CSIC-UIB), C/Miquel Marqués 21, E-07190 Esporles, \\ Mallorca, Spain \\ ${ }^{3}$ Institute of Microbiology and Genetics, University of Vienna, A-1030 Vienna, Austria
}

Four coagulase-negative, novobiocin-resistant cocci, designated $\mathrm{CW} 1^{\top}, \mathrm{PM} 34, \mathrm{MM} 3$ and RW78, were isolated from the respiratory tract of goats kept in the Himalayan region. The four isolates were assigned to a single species on the basis of almost identical biochemical and physiological traits, protein profiles obtained after SDS-PAGE and identical genomic fingerprints generated after enterobacterial repetitive intergenic consensus (ERIC)-PCR. Strain $C W 1^{\top}$ showed highest 16S rDNA sequence similarities to Staphylococcus cohnii subsp. urealyticus ATCC $49330^{\top}$, Staphylococcus saprophyticus subsp. saprophyticus ATCC $15305^{\top}$, S. cohnii subsp. cohnii ATCC $29974^{\top}$, Staphylococcus arlettae ATCC $43957^{\top}$, Staphylococcus gallinarum ATCC $35539^{\top}$, Staphylococcus succinus ATCC $700337^{\top}$ and Staphylococcus xylosus ATCC $29971^{\top}(99 \cdot 0,98 \cdot 8,98 \cdot 8,98 \cdot 4,98 \cdot 2,98 \cdot 1$ and $98 \cdot 1 \%$, respectively), indicating its classification within the genus Staphylococcus. The polar lipid composition, fatty acid profiles, quinone systems and diagnostic cell-wall diamino acid were in agreement with the characteristics of the genus Staphylococcus. DNA-DNA hybridization with closely related Staphylococcus species suggested that strain $\mathrm{CW} 1^{\top}$ represents an as-yet unrecognized species. Based on these results, a novel species of the genus Staphylococcus is described, Staphylococcus nepalensis sp. nov. The type strain is $\mathrm{CW} 1^{\top}\left(=\mathrm{DSM} 15150^{\top}=\mathrm{CCM} 7045^{\top}\right)$ and the most dissimilar strain is PM34 (=DSM 15151 = CCM 7046).
Staphylococci are ubiquitous and diverse organisms widespread in nature. At the time of writing, the genus Staphylococcus consists of 38 species (Holt et al., 1994; Lambert et al., 1998; Vernozy-Rozand et al., 2000). Several Staphylococcus species have been isolated from various mammals and birds. In the caprine host, Staphylococcus species have been recovered from skin and mucous membranes, as well as from goat products such as milk and cheese (Devriese et al., 1985; Valle et al., 1991; Ferrer et al., 1997; Klinger \& Rosenthal, 1997; Mahanta et al., 1997; Bedidi-Madani et al., 1998; Vernozy-Rozand et al., 2000; Place et al., 2002). In the course of a study to determine the prevalence and significance of bacteria in the respiratory

Published online ahead of print on 6 June 2003 as DOI 10.1099/ ijs.0.02646-0.

The EMBL accession number for the $16 \mathrm{~S}$ rDNA sequence of strain $\mathrm{CW} 1^{\top}$ is AJ517414.

SDS-PAGE profiles of whole-cell lysates of the novel isolates and reference Staphylococcus species are available as supplementary material in IJSEM Online. tract of goats with pneumonia from different areas of the Himalayan region, a small number of unidentified staphylococci were isolated. Preliminary routine investigations demonstrated that they were coagulase-negative and resistant towards novobiocin. The cluster of staphylococci that share these traits consists of Staphylococcus arlettae, Staphylococcus cohnii, Staphylococcus equorum, Staphylococcus gallinarum, Staphylococcus kloosii, Staphylococcus saprophyticus, Staphylococcus succinus and Staphylococcus xylosus. Phylogenetically, these species are located on a separate subline within the genus Staphylococcus (Takahashi et al., 1999). Here, we report the characterization and classification of four isolates, for which we propose the name Staphylococcus nepalensis sp. nov.

The four strains were recovered from three nasal swabs (PM34, RW78, CW1 ${ }^{\mathrm{T}}$ ) and one lung sample (MM3) collected from four goats with respiratory symptoms kept in different areas of Nepal (Pakhribas, Mangalbare, Rajarani, Chitwan). The organisms were isolated on blood agar base no. 2 (Oxoid) supplemented with $5 \%(\mathrm{v} / \mathrm{v})$ defibrinated sheep blood that was incubated aerobically at $37^{\circ} \mathrm{C}$ for $24 \mathrm{~h}$. 
Subcultivation was done on trypticase soy agar (BBL) or trypticase soy broth (BBL). Type strains of Staphylococcus species were supplied by the American Type Culture Collection, Manassas, VA, USA (ATCC), the Deutsche Sammlung von Mikroorganismen und Zellkulturen, Braunschweig, Germany (DSMZ), and the Czech Collection of Microorganisms, Masaryk University, Brno, Czech Republic (CCM).

\section{5 rDNA sequence analyses}

$16 \mathrm{~S}$ rDNA of strain $\mathrm{CW} 1^{\mathrm{T}}$ was amplified and sequenced as described by Wieser et al. (1999) and PCR products were purified using a GenElute purification kit (Sigma). The derived sequence was aligned and compared with other bacterial 16S rRNA sequences available in the EMBL database using the Wisconsin package (GCG, 1995). The 16S rDNA sequence of strain $\mathrm{CW1}^{\mathrm{T}}$ consisted of 1470 nucleotides (positions 31-1492, Escherichia coli numbering; Brosius et al., 1978). Sequence comparisons using FASTA (Pearson \& Lipman, 1988) demonstrated that strain CW $1^{\mathrm{T}}$ is a member of the genus Staphylococcus. Highest sequence similarity values were obtained to $S$. cohnii subsp. urealyticus ATCC $49330^{\mathrm{T}}$, S. saprophyticus subsp. saprophyticus ATCC $15305^{\mathrm{T}}$, S. cohnii subsp. cohnii ATCC $29974^{\mathrm{T}}$, S. arlettae ATCC $43957^{\mathrm{T}}$, S. gallinarum ATCC $35539^{\mathrm{T}}$, S. succinus ATCC $700337^{\mathrm{T}}$ and S. xylosus ATCC $29971^{\mathrm{T}}(99 \cdot 0,98 \cdot 8$, $98 \cdot 8,98 \cdot 4,98 \cdot 2,98 \cdot 1$ and $98 \cdot 1 \%$, respectively).

\section{Physiological characterization and antibiotic susceptibilities}

Morphological and physiological characteristics as well as susceptibility to lysostaphin, lysozyme, furazolidone, novobiocin, bacitracin and the vibriostatic compound O/129 were examined as described previously (Hájek et al., 1992; Freney et al., 1999). Susceptibility to other antibiotics was determined on Mueller-Hinton agar (Oxoid) by a standard diffusion technique using antibiotic-impregnated disks (Oxoid). Any sign of growth inhibition, after $24 \mathrm{~h}$ incubation at $37^{\circ} \mathrm{C}$, was scored. Other traits were examined using API ID 32 Staph and API $50 \mathrm{CH}$ strips (bioMérieux). Characteristics of the four strains PM34, MM3, RW78 and $\mathrm{CW}^{\mathrm{T}}$ are summarized in the species description below and in Table 1.

\section{Chemotaxonomic investigation}

Menaquinones were analysed as described previously (Tindall, 1990; Altenburger et al., 1996). Quinone systems consisted of the major menaquinone MK-7 (71-74\%) and minor amounts of MK-6 (10-16\%) and MK-8 (10-18\%). A similar quinone system with the predominant compound MK-7 has been reported for numerous Staphylococcus species, including strains of $S$. cohnii, S. saprophyticus and S. xylosus (Nahaie et al., 1984). Polar lipids were extracted and analysed by two-dimensional TLC according to Ventosa et al. (1993). The polar lipid profiles of the three analysed strains were homogeneous. They consisted of the major
Table 1. Characteristics that differentiate $S$. nepalensis sp. nov. from other novobiocin-resistant, oxidase-negative Staphylococcus species

Species: 1, S. nepalensis sp. nov. (four strains); 2, S. arlettae; 3, S. cohnii subsp. cohnii; 4, S. cohnii subsp. urealyticus; 5, S. equorum; 6, S. gallinarum; 7, S. kloosii; 8, S. saprophyticus subsp. saprophyticus; 9, S. saprophyticus subsp. bovis; 10, S. succinus subsp. succinus; 11, S. xylosus. Data for reference species were taken from Behme et al. (1996) and Freney et al. (1999). Results are scored as: ,$+ \geqslant 90 \%$ of strains positive; $\mathrm{d}, 11-89 \%$ of strains positive; ,$- 0-10 \%$ of strains positive.

\begin{tabular}{|c|c|c|c|c|c|c|c|c|c|c|c|}
\hline Characteristic & 1 & 2 & 3 & 4 & 5 & 6 & 7 & 8 & 9 & 10 & 11 \\
\hline Urease activity & + & + & - & + & + & + & + & + & + & + & + \\
\hline Nitrate reduction & + & - & - & - & + & + & - & - & + & - & + \\
\hline Aesculin hydrolysis & + & + & - & $\mathrm{d}$ & $\mathrm{d}$ & + & $\mathrm{d}$ & - & - & + & $\mathrm{d}$ \\
\hline Tween 80 hydrolysis & + & - & $\mathrm{d}$ & $\mathrm{d}$ & - & - & - & - & - & - & - \\
\hline Pyrrolidonyl arylamidase & + & - & - & $\mathrm{d}$ & - & - & $\mathrm{d}$ & $\mathrm{d}$ & - & - & $\mathrm{d}$ \\
\hline \multicolumn{12}{|l|}{ Acid production from: } \\
\hline L-Arabinose & + & + & - & - & $\mathrm{d}$ & + & $\mathrm{d}$ & - & $\mathrm{d}$ & + & $\mathrm{d}$ \\
\hline D-Cellobiose & - & - & - & - & d & + & - & - & - & + & - \\
\hline D-Galactose & + & - & $\mathrm{d}$ & $\mathrm{d}$ & $\mathrm{d}$ & - & - & - & + & + & $\mathrm{d}$ \\
\hline Salicin & + & - & - & $\mathrm{d}$ & + & + & - & - & - & - & - \\
\hline
\end{tabular}

lipids diphosphatidylglycerol, phosphatidylglycerol and a glycolipid. The chromatographic behaviour of this glycolipid corresponded to a glycolipid $\mathrm{G}_{1}$, which was assumed to be $\beta$-gentiobiosyl diacylglycerol (Nahaie et al., 1984). Additionally, two unknown aminophospholipids, three unknown glycolipids and one unknown polar lipid were detected. Concerning the major components, this polar lipid profile was in good agreement with the profiles of S. cohnii NCTC $11041^{\mathrm{T}}$, S. saprophyticus $\mathrm{SCH} 94^{\mathrm{T}}$ and S. xylosus NCTC $11043^{\mathrm{T}}$ (Nahaie et al., 1984). Diagnostic cell-wall diamino acids were extracted from cell walls as described by Schleifer (1985) and identified by comparison with the chromatographic behaviour of references. The characteristic cell-wall diamino acid of strains $\mathrm{CW}_{1}{ }^{\mathrm{T}}$, PM34 and MM3 was L-lysine, which was reported to be characteristic of staphylococci (Kloos et al., 1992).

Fatty acids were extracted from biomass grown at $28^{\circ} \mathrm{C}$ for $24 \mathrm{~h}$ on trypticase soy agar according to Osterhout et al. (1991) and analysed using GLC (Wieser et al., 1999). In the fatty acid profiles, the predominant fatty acids were ai- $\mathrm{C}_{15: 0}, \mathrm{i}-\mathrm{C}_{15: 0}$ and ai- $\mathrm{C}_{17: 0}$, whilst $\mathrm{i}-\mathrm{C}_{17: 0}, \mathrm{C}_{18: 0}, \mathrm{C}_{16: 0}$ and $\mathrm{C}_{20: 0}$ were present in moderate amounts (Table 2). Similar fatty acid profiles were reported for several Staphylococcus species by Kotilainen et al. (1991). The combination of these chemotaxonomic characteristics supports the assignment of the isolates to the genus Staphylococcus.

For analysis of protein patterns, SDS-PAGE of the four isolates and their nearest related Staphylococcus species was performed as described previously (Laemmli, 1970; Rosengarten et al., 1994). Each of the 11 species and subspecies displayed a unique band profile, allowing their 
Table 2. Fatty acid composition of S. nepalensis $\mathrm{CW}^{\top}$ Values in parentheses indicate the range detected for the four strains.

\begin{tabular}{|lc|}
\hline Fatty acid & Content $($ range $)(\%)$ \\
\hline $\mathrm{C}_{12: 0}$ & $0 \cdot 4(0 \cdot 0-0 \cdot 4)$ \\
$\mathrm{i}-\mathrm{C}_{14: 0}$ & $0 \cdot 3(0 \cdot 3-0 \cdot 5)$ \\
$\mathrm{C}_{14: 0}$ & $0 \cdot 7(0 \cdot 7)$ \\
$\mathrm{i}-\mathrm{C}_{15: 0}$ & $20 \cdot 7(18 \cdot 0-20 \cdot 7)$ \\
ai- $\mathrm{C}_{15: 0}$ & $42 \cdot 9(41 \cdot 8-43 \cdot 9)$ \\
$\mathrm{C}_{15: 0}$ & $0 \cdot 2(0 \cdot 0-0 \cdot 2)$ \\
$\mathrm{i}-\mathrm{C}_{16: 0}$ & $1 \cdot 3(1 \cdot 0-1 \cdot 4)$ \\
$\mathrm{C}_{16: 0}$ & $3 \cdot 8(3 \cdot 3-3 \cdot 8)$ \\
$\mathrm{i}-\mathrm{C}_{17: 0}$ & $7 \cdot 3(6 \cdot 6-7 \cdot 3)$ \\
ai- $\mathrm{C}_{17: 0}$ & $13 \cdot 1(13 \cdot 1-14 \cdot 8)$ \\
$\mathrm{C}_{18: 0}$ & $4 \cdot 6(4 \cdot 5-4 \cdot 7)$ \\
$\mathrm{i}-\mathrm{C}_{19: 0}$ & $1 \cdot 5(1 \cdot 5-2 \cdot 0)$ \\
ai- $\mathrm{C}_{19: 0}$ & $0 \cdot 0(0 \cdot 0-1 \cdot 3)$ \\
$\mathrm{C}_{20: 0}$ & $3 \cdot 0(3 \cdot 0-4 \cdot 4)$ \\
\hline
\end{tabular}

differentiation from each other (see supplementary material available in IJSEM Online). Partial similarities were observed between S. succinus subsp. succinus ATCC $700337^{\mathrm{T}}$ and S. kloosii CCM $3834^{\mathrm{T}}$, S. arlettae CCM $3830^{\mathrm{T}}$, S. cohnii subsp. cohnii CCM $2736^{\mathrm{T}}$ and S. cohnii subsp. urealyticus CCM $4294^{\mathrm{T}}$, and S. saprophyticus subsp. saprophyticus CCM $883^{\mathrm{T}}$ and $\mathrm{CW} 1^{\mathrm{T}}$, but almost identical protein profiles were only detected for isolates PM34, MM3, RW78 and CW1 ${ }^{\mathrm{T}}$. These results support assignment of the four isolates to a single species that has not yet been recognized.

\section{Genomic analysis}

The DNA extraction protocol was based on a previously described procedure (Lambert et al., 1998). Determination of DNA G + C content was performed as described by Wieser et al. (1999). The G $+C$ content of the genomic DNA of $\mathrm{CW}^{\mathrm{T}}$ was $33 \mathrm{~mol} \%$, which is in the range reported for other Staphylococcus species (Kloos \& Schleifer, 1986).
Enterobacterial repetitive intergenic consensus (ERIC)-PCR has been shown to be a useful approach for identification of Staphylococcus epidermidis and its differentiation from related species. In order to examine this approach for identification of our four isolates, their ERIC-fingerprints, generated as described by Wieser \& Busse (2000) using a Gene Amp PCR System 2400 thermal cycler (Perkin Elmer Applied Biosystems), were analysed. Each isolate displayed a single band consisting of approximately $640 \mathrm{bp}$ (Fig. 1). Other Staphylococcus species that were considered to be the nearest relatives of $\mathrm{CW}^{\mathrm{T}}$ based on $16 \mathrm{~S}$ rDNA sequence similarity values exhibited clearly distinguishable banding patterns. These observations indicated that the four isolates are members of a single novel species.

DNA-DNA hybridization was performed according to Ziemke et al. (1998) under optimal conditions at $58^{\circ} \mathrm{C}$ $\left(30^{\circ}\right.$ below the melting temperature of the homoduplex DNA; $T_{\mathrm{m}}=88^{\circ} \mathrm{C}$ ). The results (Table 3) demonstrated that strain $\mathrm{CW}^{\mathrm{T}}$ represents a novel species of the genus Staphylococcus.

RAPD (randomly amplified polymorphic DNA) PCRs were performed by using RAPD primers 1 to 6 of the RAPD analysis primer set (Amersham Pharmacia Biotech) according to the instructions of the manufacturer. Genomic fingerprints were distinct for each strain, indicating that isolates PM34, MM3, RW78 and $\mathrm{CW1}^{\mathrm{T}}$ are not clonally related (results not shown).

Based on the results presented here, it is demonstrated that strains PM34, MM3, RW78 and CW1 ${ }^{\mathrm{T}}$ are members of a novel species of the genus Staphylococcus, for which we propose the name Staphylococcus nepalensis sp. nov.

\section{Description of Staphylococcus nepalensis sp. nov.}

Staphylococcus nepalensis (ne.pa.len'sis. N.L. masc. adj. nepalensis pertaining to the kingdom of Nepal, where clinical samples for bacteriological examination were collected from local goats).
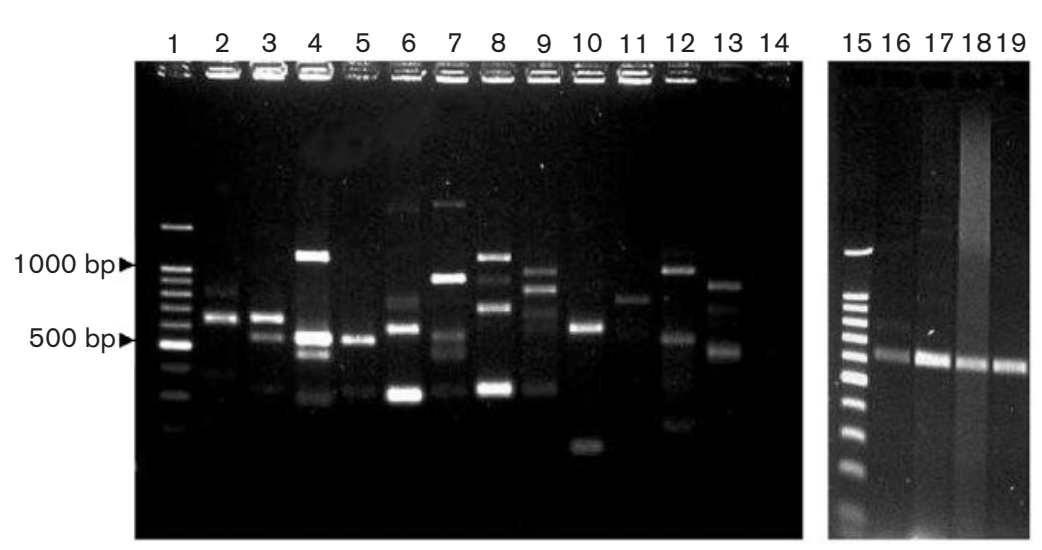

Fig. 1. ERIC-PCR-generated DNA fingerprints of Staphylococcus species. Lanes: 1 and 15, 100 bp ladder; 2 and 16, S. nepalensis $\mathrm{CW}_{1}{ }^{\mathrm{T}} ; 3$, S. cohnii subsp. urealyticus CCM 4294 ${ }^{\top} ; 4$, S. cohnii subsp. cohnii CCM $2736^{\top} ; 5$, S. saprophyticus subsp. saprophyticus CCM $883^{\top} ; 6$, S. xylosus DSM $20231^{\top} ; 7$, S. equorum CCM $3832^{\top}$; 8 , S. succinus subsp. succinus ATCC $700337^{\top} ;$ 9, S. kloosii CCM $3834^{\top} ; 10$, S. lugdunensis CCM 4064 $4^{\mathrm{T}} ; 11$, S. arlettae CCM $3830^{\top} ; 12, \quad S$. haemolyticus DSM $20263^{\top} ; 13$, S. gallinarum DSM 20610'; 14, negative control; 17-19, S. nepalensis strains PM34, MM3 and RW78. 
Table 3. DNA-DNA relatedness between $S$. nepalensis $\mathrm{CW}^{\top}$ and $S$. xylosus DSM $20231^{\top}$ and other species in the genus Staphylococcus

\begin{tabular}{|c|c|c|}
\hline \multirow[t]{2}{*}{ Strain } & \multicolumn{2}{|c|}{ DNA-DNA relatedness $(\%)$ to: } \\
\hline & S. nepalensis $\mathrm{CW} 1^{\mathrm{T}}$ & S. xylosus DSM $20231^{\mathrm{T}}$ \\
\hline S. nepalensis $\mathrm{CW} 1^{\mathrm{T}}$ & 100 & 52 \\
\hline S. xylosus DSM $20231^{\mathrm{T}}$ & 68 & 100 \\
\hline S. lugdunensis CCM $4064^{\mathrm{T}}$ & 65 & 34 \\
\hline S. gallinarum DSM $20610^{\mathrm{T}}$ & 64 & 44 \\
\hline S. saprophyticus subsp. saprophyticus CCM $883^{\mathrm{T}}$ & 63 & 63 \\
\hline S. arlettae CCM $3830^{\mathrm{T}}$ & 58 & ND \\
\hline S. cohnii subsp. cohnii CCM $2736^{\mathrm{T}}$ & 56 & 43 \\
\hline S. equorum CCM $3832^{\mathrm{T}}$ & 53 & 47 \\
\hline S. succinus subsp. succinus ATCC $700337^{\mathrm{T}}$ & 51 & 51 \\
\hline S. kloosii CCM $3834^{\mathrm{T}}$ & 47 & 37 \\
\hline S. haemolyticus DSM $20263^{\mathrm{T}}$ & 43 & 42 \\
\hline S. cohnii subsp. urealyticus CCM $4294^{\mathrm{T}}$ & 42 & ND \\
\hline
\end{tabular}

ND, Not determined.

Cells are Gram-positive cocci, $1 \cdot 1-1 \cdot 6 \mu \mathrm{m}$ in diameter, that occur singly, in pairs and in irregular clusters. Motility is not observed. Colonies after 2 days on $\mathrm{P}$ agar are circular, low-convex, smooth, glossy, opaque white and $2-6 \mathrm{~mm}$ in diameter. Growth occurs aerobically and anaerobically in the presence of $0-7 \cdot 5 \% \mathrm{NaCl}(\mathrm{w} / \mathrm{v})$. The type strain grows well in the presence of $10 \% \mathrm{NaCl}(\mathrm{w} / \mathrm{v})$, but growth is variable for other strains. No growth is observed in the presence of $15 \% \mathrm{NaCl}$. Growth occurs between 20 and $40{ }^{\circ} \mathrm{C}$, best growth at $30^{\circ} \mathrm{C}$. No growth at 15 or $45^{\circ} \mathrm{C}$. Oxidase-negative. Catalase-positive. Produces urease, alkaline phosphatase, pyrrolidonyl arylamidase, $\beta$-galactosidase and $\beta$-glucuronidase. Hydrolyses aesculin and Tween 80 . Reduces nitrate to nitrite. Positive for aerobic production of acid from D-glucose, D-fructose, D-mannose, maltose, lactose, trehalose, mannitol, sucrose, L-arabinose, $\mathrm{N}$ acetylglucosamine, galactose, glycerol, erythritol, D-xylose, arbutin and salicin. Negative for oxidase activity, clumping factor, coagulase, hyaluronidase, arginine dihydrolase, ornithine decarboxylase, acetoin, arginine arylamidase, $\alpha$ - and $\beta$-haemolysins, heat-stable and heat-labile nucleases, indole, hydrogen sulphide and lecithinase. Acid is not formed aerobically from D-raffinose, ribose, D-cellobiose, D-arabinose, L-xylose, adonitol, methyl $\beta$-D-xyloside, rhamnose, L-sorbose, dulcitol, starch, inositol, methyl $\alpha$ D-mannoside, methyl $\alpha$-D-glucoside, amygdalin, melibiose, melezitose, gentiobiose, glycogen, inulin, D-tagatose, Dlyxose, cellobiose, D-fucose, L-fucose, L-arabitol, gluconate, 2-ketogluconate or 5-ketogluconate. Acid production from D-arabitol, sorbitol, turanose and xylitol is variable; the type strain is positive. Resistant to novobiocin, bacitracin, vibriostatic agent O/129, lysozyme, metronidazole and optochin. Susceptible to lysostaphin, furazolidone, ampicillin, amoxicillin, amoxicillin/clavulanic acid, ceftiofur, cephalexin, cephalothin, chloramphenicol, clindamycin, colistin sulphate, enrofloxacin, erythromycin, florfenicol, fosfomycin, fusidic acid, gentamicin, kanamycin, lincomycin, neomycin, nitrofurantoin, oxacillin, penicillin G, polymyxin $B$, sulfamethoxazole/trimethoprim, tetracycline and vancomycin. The quinone system consists of the major menaquinone MK-7 and minor amounts of MK-6 and MK-8. Predominant fatty acids are ai- $\mathrm{C}_{15: 0}, \mathrm{i}-\mathrm{C}_{15: 0}$ and ai- $\mathrm{C}_{17: 0}$, whilst $\mathrm{i}-\mathrm{C}_{17: 0}, \mathrm{C}_{18: 0}, \mathrm{C}_{16: 0}, \mathrm{C}_{20: 0}$ and $\mathrm{i}-\mathrm{C}_{19: 0}$ are present in moderate amounts. Polar lipid profile consists of the major lipids diphosphatidylglycerol, phosphatidylglycerol and an unknown glycolipid (assumed to be $\beta$ gentiobiosyl diacylglycerol). Additionally, minor amounts of two unknown aminophospholipids and three unknown glycolipids are detected. The $\mathrm{G}+\mathrm{C}$ content of the type strain is $33 \mathrm{~mol} \%$ (HPLC).

The type strain is $\mathrm{CW}^{\mathrm{T}}\left(=\mathrm{DSM} 15150^{\mathrm{T}}=\mathrm{CCM} 7045^{\mathrm{T}}\right)$ and the most dissimilar strain is PM34 (=DSM $15151=$ CCM 7046).

\section{Acknowledgements}

The authors thank T. Beier for kindly providing clinical samples and S. Wildmann and M. Valens for skilled technical assistance.

\section{References}

Altenburger, P., Kämpfer, P., Makristathis, A., Lubitz, W. \& Busse, H.-J. (1996). Classification of bacteria isolated from a medieval wall painting. J Biotechnol 47, 39-52.

Bedidi-Madani, N., Greenland, T. \& Richard, Y. (1998). Exoprotein and slime production by coagulase-negative staphylococci isolated from goats' milk. Vet Microbiol 59, 139-145.

Behme, R. J., Shuttleworth, R., McNabb, A. \& Colby, W. D. (1996). Identification of staphylococci with a self-educating system using fatty acid analysis and biochemical tests. J Clin Microbiol 34, 3075-3084. 
Brosius, J., Palmer, M. L., Kennedy, P. J. \& Noller, H. F. (1978). Complete nucleotide sequence of a $16 \mathrm{~S}$ ribosomal RNA gene from Escherichia coli. Proc Natl Acad Sci U S A 75, 4801-4805.

Devriese, L. A., Schleifer, K. H. \& Adegoke, G. O. (1985). Identification of coagulase-negative staphylococci from farm animals. J Appl Bacteriol 58, 45-55.

Ferrer, O., Real, F., Molina, J. M., Acosta, B., Munoz, M. C. \& Leon, L. (1997). IgG concentration in mammary secretions of goats throughout lactation in healthy and coagulase-negative staphylococci infected udders. Comp Immunol Microbiol Infect Dis 20, 253-260.

Freney, J., Kloos, W. E., Hajek, V., Webster, J. A., Bes, M., Brun, Y. \& Vernozy-Rozand, C. (1999). Recommended minimal standards for description of new staphylococcal species. Subcommittee on the taxonomy of staphylococci and streptococci of the International Committee on Systematic Bacteriology. Int J Syst Bacteriol 49, 489-502.

GCG (1995). Wisconsin Package Version 8.1 Program Manual. Madison, WI: Genetics Computer Group.

Hájek, V., Ludwig, W., Schleifer, K. H., Springer, N., Zitzelsberger, W., Kroppenstedt, R. M. \& Kocur, M. (1992). Staphylococcus muscae, a new species isolated from flies. Int J Syst Bacteriol 42, 97-101.

Holt, J. G., Krieg, N. R., Sneath, P. H. A., Staley, J. T. \& Williams, S. T. (editors) (1994). Bergey's Manual of Determinative Bacteriology, 9th edn. Baltimore: Williams \& Wilkins.

Klinger, I. \& Rosenthal, I. (1997). Public health and the safety of milk and milk products from sheep and goats. Rev Sci Tech 16, 482-488.

Kloos, W. E. \& Schleifer, K. H. (1986). Genus IV. Staphylococcus Rosenbach 1884, $18^{\mathrm{AL}}$. In Bergey's Manual of Systematic Bacteriology, vol. 2, pp. 1013-1035. Edited by P. H. A. Sneath, N. S. Mair, M. E. Sharpe \& J. G. Holt. Baltimore: Williams \& Wilkins.

Kloos, W. E., Schleifer, K. H. \& Götz, F. (1992). The genus Staphylococcus. In The Prokaryotes, 2nd edn, pp. 1369-1420. Edited by A. Balows, H. G. Trüper, M. Dworkin, W. Harder \& K. H. Schleifer. New York: Springer.

Kotilainen, P., Huovinen, P. \& Eerola, E. (1991). Application of gas-liquid chromatographic analysis of cellular fatty acids for species identification and typing of coagulase-negative staphylococci. J Clin Microbiol 29, 315-322.

Laemmli, U. K. (1970). Cleavage of structural proteins during the assembly of the head of bacteriophage T4. Nature 227, 680-685.

Lambert, L. H., Cox, T., Mitchell, K., Rosselló-Mora, R. A., Del Cueto, C., Dodge, D. E., Orkand, P. \& Cano, R. J. (1998). Staphylococcus succinus sp. nov., isolated from Dominican amber. Int J Syst Bacteriol 48, 511-518.

Lane, D. J. (1991). 16S/23S rRNA sequencing. In Nucleic Acid Techniques in Bacterial Systematics, pp. 115-175. Edited by E. Stackebrandt \& M. Goodfellow. Chichester: Wiley.
Mahanta, P. N., Thungchamo, K., Dutta, G. N. \& Devriese, L. A. (1997). Identification and characterization of staphylococci isolated from cutaneous lesions of goats. Zentbl Veterinarmed B 44, 309-311.

Nahaie, M. R., Goodfellow, M., Minnikin, D. E. \& Hájek, V. (1984). Polar lipid and isoprenoid quinone composition in the classification of Staphylococcus. J Gen Microbiol 130, 2427-2437.

Osterhout, G. J., Shull, V. H. \& Dick, J. D. (1991). Identification of clinical isolates of gram-negative nonfermentative bacteria by an automated cellular fatty acid identification system. J Clin Microbiol 29, 1822-1830.

Pearson, W. R. \& Lipman, D. J. (1988). Improved tools for biological sequence comparison. Proc Natl Acad Sci U S A 85, 2444-2448.

Place, R. B., Hiestand, D., Burri, S. \& Teuber, M. (2002). Staphylococcus succinus subsp. casei subsp. nov., a dominant isolate from a surface ripened cheese. Syst Appl Microbiol 25, 353-359.

Rosengarten, R., Behrens, A., Stetefeld, A., Heller, M., Ahrens, M., Sachse, K., Yogev, D. \& Kirchhoff, H. (1994). Antigen heterogeneity among isolates of Mycoplasma bovis is generated by high-frequency variation of diverse membrane surface proteins. Infect Immun 62, 5066-5074.

Schleifer, K. H. (1985). Analysis of the chemical composition and primary structure of murein. Methods Microbiol 18, 123-156.

Takahashi, T., Satoh, I. \& Kikuchi, N. (1999). Phylogenetic relationships of 38 taxa of the genus Staphylococcus based on 16S rRNA gene sequence analysis. Int J Syst Bacteriol 49, 725-728.

Tindall, B. J. (1990). Lipid composition of Halobacterium lacusprofundi. FEMS Microbiol Lett 66, 199-202.

Valle, J., Piriz, S., de la Fuenta, R. \& Vadillo, S. (1991). Staphylococci isolated from healthy goats. Zentbl Veterinarmed B 38, 81-89.

Ventosa, A., Marquez, M. C., Kocur, M. \& Tindall, B. J. (1993). Comparative study of "Micrococcus sp." strains CCM 168 and CCM 1405 and members of the genus Salinicoccus. Int J Syst Bacteriol 43, 245-248.

Vernozy-Rozand, C., Mazuy, C., Meugnier, H., Bes, M., Lasne, Y., Fiedler, F., Etienne, J. \& Freney, J. (2000). Staphylococcus fleurettii sp. nov., isolated from goat's milk cheeses. Int J Syst Evol Microbiol 50, 1521-1527.

Wieser, M. \& Busse, H.-J. (2000). Rapid identification of Staphylococcus epidermidis. Int J Syst Evol Microbiol 50, 1087-1093.

Wieser, M., Schumann, P., Martin, K., Altenburger, P., Burghardt, J., Lubitz, W. \& Busse, H.-J. (1999). Agrococcus citreus sp. nov., isolated from a medieval wall painting of the chapel of Castle Herberstein (Austria). Int J Syst Bacteriol 49, 1165-1170.

Ziemke, F., Höfle, M. G., Lalucat, J. \& Rosselló-Mora, R. (1998). Reclassification of Shewanella putrefaciens Owen's genomic group II as Shewanella baltica sp. nov. Int J Syst Bacteriol 48, 179-186. 